\title{
A Course about the Environment for All Engineering Students
}

\author{
Paul Henshaw, Ph.D., P.Eng. \\ Associate Professor, Department of Civil and Environmental Engineering \\ University of Windsor \\ henshaw@uwindsor.ca
}

\begin{abstract}
The course 85-250 Engineering and the Environment began in 2009 and has been delivered to two cohorts of students at the University of Windsor. This course is currently required for sophomore Environmental, Civil, Mechanical and Industrial undergraduates (approximately 180 students), and provides them with environmental awareness in order to achieve the graduate attribute 3.1.9 Impact of Engineering on [Society and] the Environment. In addition, the course curriculum is shaped by two Engineers Canada exam syllabi. The course begins with basic biological concepts of how matter cycles and energy flows in nature, and philosophical concepts in resource allocation/pollution (e.g. tragedy of the commons), and then quantitative elements of dimensions, risk calculation and mass balances are introduced. The latter part of the course examines applications of these principles to two topics of interest to a broad range of engineering disciplines: pollution prevention and energy conversion.

Delivery of the course is by traditional lecture format supplemented by weekly tutorials with approximately 50 students each. Tutorial assignments consist of either individual problem solving (quantitative material) or group problem solving (philosophical concepts). Evaluation is through submitted tutorial assignments, clicker questions, exams (two mid-term and one final), an online minicourse, and presentation of a group project. All exams are multiple-choice, with an instant feedback assessment technique used in the mid-terms. Students complete a self-contained online mini course in Occupational Health and Safety, which includes WHMIS training. The textbook is a custom print product which includes chapters extracted from three textbooks supplied by the publisher. Student feedback regarding methods of delivery and evaluation will be presented.
\end{abstract}

1 Introduction

Prior to the introduction of this course, engineering students were allowed to pick from a number of "nontechnical" electives to satisfy requirements for environmental awareness in the engineering curriculum. These offerings did not provide a consistent focus on the issues needed for engineering students. In the 2008 revision of the curriculum, a new course was created: 85-250 Engineering and the Environment. This course was offered in the fall terms of 2009 and 2010 as a mandatory course for $2^{\text {nd }}$ year engineering students. The breakdown by initial registration was 34\% Civil, 10\% Environmental, 7\% Industrial, 46\% Mechanical, and 4\% other (average class size $=188$ ). At that point in their curriculum, students are in their third semester and have completed basic chemistry (the only listed prerequisite, although students must complete $80 \%$ of the $1^{\text {st }}$ year program in order to register for $2^{\text {nd }}$ year), physics and thermofluids (introductions to thermodynamics, fluid mechanics and heat transfer).

\section{Syllabus}

Engineers Canada publishes exam syllabi for applicants who wish to become professional engineers, but did not graduate from a CEAB accredited program. Although, the exams are not intended to "establish mandatory subjects that must be mastered in each discipline"[1], the exam syllabi serve as an excellent guideline to developing engineering courses. The topics in $85-250$ were mainly derived from the exam syllabi for 98-CS-2 Engineering in Society Health, Safety and the Environment, a required exam for all engineers [2], and 98-Civ-A3 Environmental Engineering, a required exam for Civil Engineering applicants [3]. Table 1 indicates how the exam syllabi are mapped into the topics and for 85-250. 
Table 1. Mapping of Engineers Canada Exam Syllabi into 85-250 Topics

\begin{tabular}{|c|c|c|}
\hline Elements from 98-CS-2 & Elements from 98-Civ-A3 & 85-250 Topics \\
\hline \multirow[t]{4}{*}{$\begin{array}{l}\text { Concepts and consideration of the environment, } \\
\text { both current and future }\end{array}$} & $\begin{array}{l}\text { The application of environmental principles } \\
\text { (technical and non-technical) to sustainable } \\
\text { development and environmental ethics }\end{array}$ & $\begin{array}{l}\text { Intoduction to } \\
\text { Environmental Problems, } \\
\text { Solutions }\end{array}$ \\
\hline & Ecology & Matter Cycles in Nature \\
\hline & Ecology & Energy Flows in Nature \\
\hline & $\begin{array}{l}\text { Population, economic growth, industrialization, as } \\
\text { causes of environmental pollution }\end{array}$ & Population \\
\hline $\begin{array}{l}\text { Overall awareness of environmental } \\
\text { considerations }\end{array}$ & $\begin{array}{l}\text { The characteristics of particles, chemistry of } \\
\text { solutions and gases }\end{array}$ & $\begin{array}{l}\text { Dimensions of } \\
\text { Contamination }\end{array}$ \\
\hline $\begin{array}{l}\text { Overall awareness of environmental } \\
\text { considerations }\end{array}$ & & Risk \\
\hline $\begin{array}{l}\text { An examination of various systems to prevent } \\
\text { environmental damage to air, water, and ground } \\
\text { systems outside of the work place environment }\end{array}$ & Material balances, reaction kinetics & Mass Balances \\
\hline $\begin{array}{l}\text { An examination of various systems to prevent } \\
\text { environmental damage to air, water, and ground } \\
\text { systems outside of the work place environment }\end{array}$ & & Pollution Prevention \\
\hline $\begin{array}{l}\text { Overall awareness of environmental } \\
\text { considerations; the role and responsibilities of an } \\
\text { engineer from a professional ethics viewpoint }\end{array}$ & $\begin{array}{l}\text { The application of environmental principles } \\
\text { (technical and non-technical) to sustainable } \\
\text { development and environmental ethics. }\end{array}$ & Legislation \\
\hline \multirow[t]{4}{*}{$\begin{array}{l}\text { An examination of various systems to prevent } \\
\text { environmental damage to air, water, and ground } \\
\text { systems outside of the work place environment }\end{array}$} & & $\begin{array}{l}\text { Energy Balances, } \\
\text { Calculations }\end{array}$ \\
\hline & Energy-use as a cause of environmental pollution & $\begin{array}{l}\text { Energy Sources - Fossil } \\
\text { Fuels }\end{array}$ \\
\hline & Energy-use as a cause of environmental pollution & Energy Sources - Nuclear \\
\hline & Energy-use as a cause of environmental pollution & $\begin{array}{l}\text { Energy Sources - } \\
\text { Renewable, Conservation }\end{array}$ \\
\hline $\begin{array}{l}\text { An examination of various systems to prevent } \\
\text { environmental damage to air outside of the work } \\
\text { place environment }\end{array}$ & $\begin{array}{l}\text { The application of environmental principles } \\
\text { (technical and non-technical) to air pollution } \\
\text { control }\end{array}$ & Air Pollution \\
\hline \multirow[t]{3}{*}{$\begin{array}{l}\text { Concepts and consideration of health, safety, both } \\
\text { current and future; awareness of the work place } \\
\text { environment with consideration to light, } \\
\text { temperature, humidity, air flow, noise, and dust } \\
\text { control; rules and regulations relating to the work } \\
\text { place environment; emergency procedures due to } \\
\text { fire, toxic gas, or chemical contamination; the role } \\
\text { and responsibilities of an engineer from a } \\
\text { professional ethics viewpoint }\end{array}$} & & Online OHS Mini-course \\
\hline & Urbanization & may be covered in projects \\
\hline & $\begin{array}{l}\text { Microbiology as related to the environment; the } \\
\text { application of environmental principles (technical } \\
\text { and non-technical) to: water resource } \\
\text { management, water and wastewater treatment, } \\
\text { solid waste management, environmental impact } \\
\text { assessment }\end{array}$ & $\begin{array}{l}\text { Covered in other courses } \\
\text { for Civil Engineers }\end{array}$ \\
\hline
\end{tabular}


In addition, the overall intent of the course is to prepare students to achieve two of the engineering graduate attributes in later courses (my underlining):

3.1.4 Design: An ability to design solutions for complex, open-ended engineering problems and to design systems, components or processes that meet specified needs with appropriate attention to health and safety risks, applicable standards, economic, environmental, cultural and societal considerations.

3.1.9 Impact of engineering on society and the environment: An ability to analyse social and environmental aspects of engineering activities. Such abilities include an understanding of the interactions that engineering has with the economic, social, health, safety, legal, and cultural aspects of society; the uncertainties in the prediction of such interactions; and the concepts of sustainable design and development and environmental stewardship. [4]

The sequence of topics in $85-250$, as shown in Table 1, was arranged so as to provide students with an understanding of natural systems (matter cycles, energy flows, population), then develop quantitative capabilities (dimensions, risk, material balances), before applying this knowledge to topics of interest. Two topics were selected which are considered to be of interest to students outside of Civil and Environmental Engineering: pollution prevention in manufacturing settings for Industrials, and energy conversion for Mechanicals and Electricals.

\section{Delivery}

Contact time over this 12-week course consists of two 80-minute lectures and one 110-minute tutorial per week. The lectures are PowerPoint presentations supplemented by short online videos (20 throughout the course). Most lectures include solving example problems, and so a tablet computer is used. Clickers (student electronic response systems) are also used in the lectures (see Section 4).

The text is a custom textbook made up of selected chapters from one engineering text [5] and two science texts [6][7] from the same publisher. One of the science texts is a Canadian edition, and was included for the Legislation and Air Pollution topics. The book is printed in black-and white with softcovers to keep the cost at around $\$ 80$. About $55 \%$ of students indicated that they would sell the text to the next cohort of students.

Four tutorial groups of maximum size 50 students each meet weekly. Tutorial exercises consist of solving problems with the help of Graduate Assistants. A tutorial either consists of quantitative problems (submitted individually), or of qualitative problems (one submission per group of three or four). In the latter type, groups may be asked to provide an example of a concept or categorize an environmental Impact. The assignments are graded and returned the next week. In one tutorial, students completed the Engineers Without Borders activity "Water for the World"[8]. In this activity, students build a water filter out of hardware-store materials, and compete to see who can produce the greatest amount of clear water from a given mixture of muddy water.

Ten percent of the course grade is allocated to an online Health and Safety mini-course. The course consists of five sections with one to four modules per section (Figure 1). Students either view a recorded presentation (PowerPoint with voiceover), or in one case, read a chapter from an online source, then complete an on-line quiz consisting of 6 to 19 questions chosen from groups of pooled questions. The questions are multiple-choice, true/false or oneword answer types. Students must answer all questions correctly before advancing to the next module. There is no time limit for the quizzes; neither is there a limit on the number of attempts by a student. At the end of each module there is a test, which consists of 4 or 5 multiple choice questions. The test is timed and only one attempt is allowed. The success of a student in answering the 24 test questions are used to calculate her/his grade on the mini-course. Students are given two months to complete the course, at their own pace. We estimate that the mini-course takes about six hours to complete.

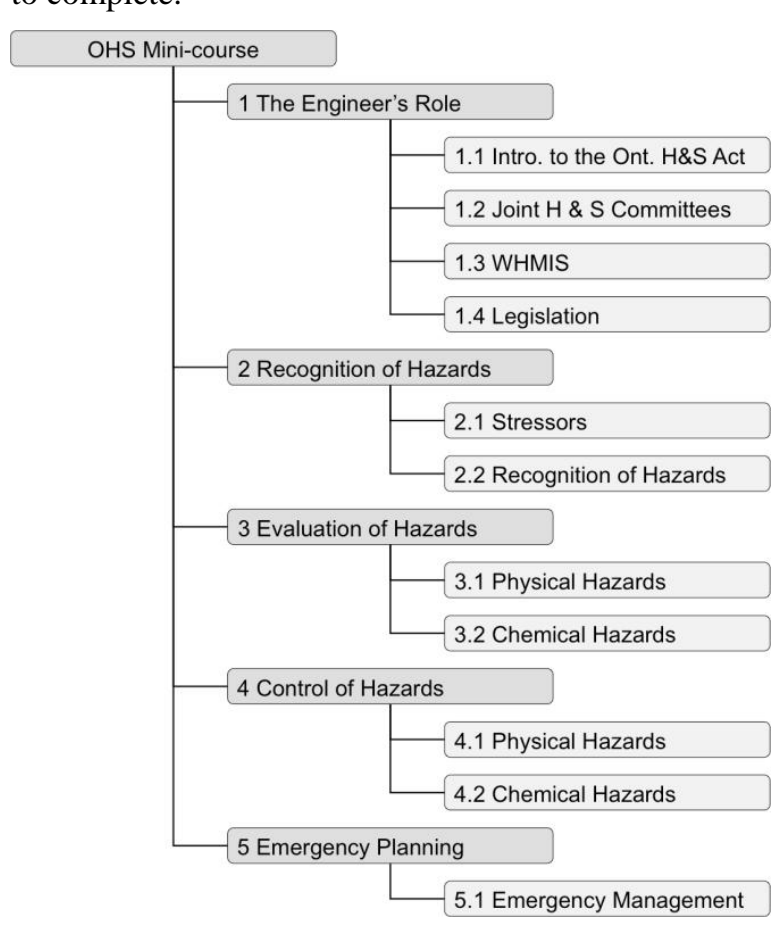

Figure 1. Sections and Modules in the Occupational Health and Safety Online Mini-course. 


\section{Grading}

Exams make up the majority of the grade in this course. There are two mid-terms (15\% each) and one final exam (30\%). All exams are multiple-choice. The mid-terms are submitted using IF-AT cards [9], in which the student indicates his/her answer by scratching to reveal a star indicating the correct answer. Thus, the student is given instant feedback about the question while s/he is still in the mode of thinking about it. This testing method has been shown to increase retention of the material [10]. In addition, partial marks are given for choosing the correct answer on the second "guess". This method of evaluation allows for breaking up successive calculations in lengthy numeric problems, knowing that the student has the opportunity to find out the correct answer at each step. Overall students liked this method of testing; as shown in Figure 2, 76 to $91 \%$ of students agreed somewhat, agreed, or strongly agreed when asked whether they preferred this method over the regular method of filling in bubbles.

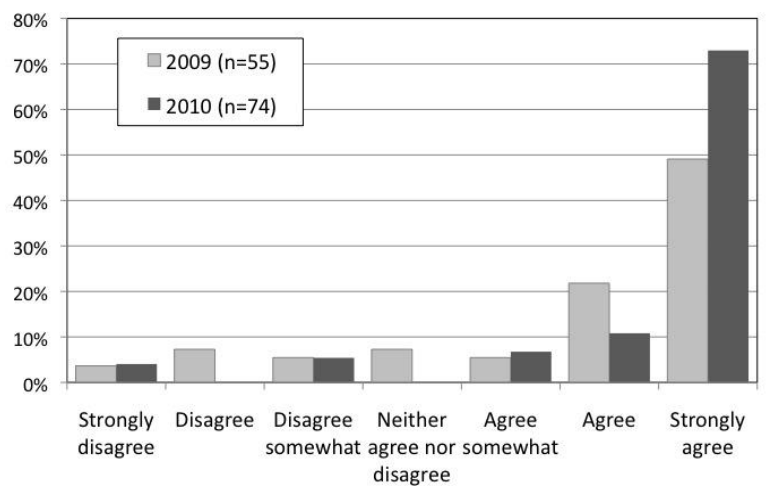

Figure 2. Student Responses to the Statement, "I preferred the IFAT (scratch to answer) method of entering answers over the Scantron method (where the answer is unknown)."

Clickers are an electronic response system that is incorporated in lectures to improve student engagement in large classes [11]. Clickers were introduced in 85-250 in 2010. Approximately three clicker questions were presented in each class, with correct answers being used to assess $5 \%$ of the grade. A number of problems with the technology (unable to save $11 \%$ of sessions, difficulty in separating "counted" questions at the end of the term) resulted in adjusting the way that this portion of grade was calculated: from taking the results of 18 "counted" questions, to taking the best 18 responses of 80 questions. As a result, $87 \%$ of the class received the maximum mark of $5 \%$. In spite of these difficulties,
$78 \%$ of the class overwhelmingly agreed that the use of clickers increased their learning in class (Figure 3).

Students presented a group project that required them to research a topic of their choice (from a list of given topics - see Table 2). These topics were intended to give students the opportunity to apply environmental thinking to their own interests, while giving them practice at presenting and working in a team. Two-thirds of students felt that the group project was a worthwhile undertaking (Figure 4).

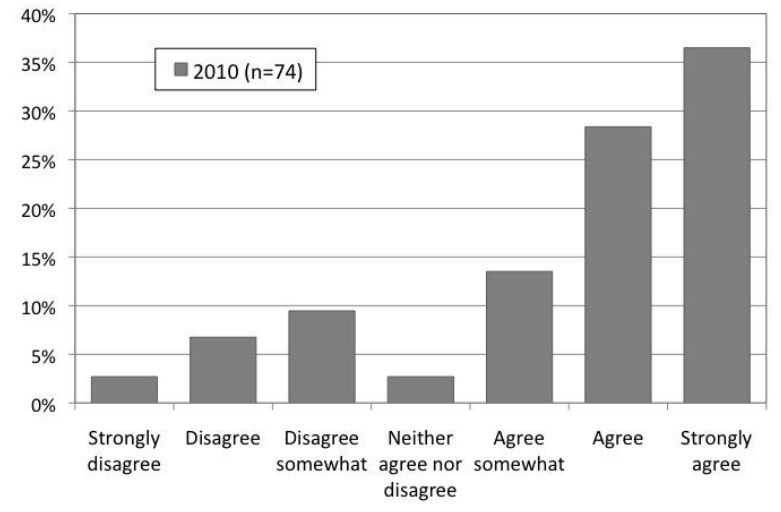

Figure 3. Student responses to the Statement, "Using a clicker increased my learning in class."

\section{Student Evaluation of Teaching}

As part of the Student Evaluation of Teaching (SET) extra questions were used to determine students' preferences for pedagogical elements of the class. Students were asked about their use of the textbook (Figure 5) and their perception of the qualitative versus quantitative balance of the course (Figure 6). Most students felt that reading the text was beneficial, but that the course was too qualitative. The latter is an interesting result, considering that students fared equally well on numeric and non-numeric exam questions. Analysis of the 2010 final exam revealed that for the average numeric question $(n=29)$, students were correct $59 \%$ of the time, and the average percent of non-numeric questions $(n=42)$ answered correctly was $61 \%$. The difference between these means is not statistically significant at the $95 \%$ level.

Overall, students' interest in the course was increased as a result of taking the course (Figure 7). There was an increase by about $18 \%$ in highly enthusiastic students at the sacrifice of medium enthusiasm students and, to a smaller extent, low enthusiasm students. In answer to the question "Considering your experience with this course, would you recommend it to other students?", 86 and $91 \%$ 


\begin{tabular}{|l|}
\hline \multicolumn{1}{|c|}{ Topics for Group Project (2010) } \\
\hline Environmental Effects of the Deepwater Horizon \\
Oil Leak \\
Municipal Waste Incineration \\
Phosphorous Effects on the Great Lakes \\
Water Diversion from the Great Lakes \\
Biomass Burners \\
Air Pollution From Trucks in Windsor \\
Nuclear Waste Disposal for Ontario's Reactors \\
Cost of Nuclear Generating Stations \\
Environmental Effect of High Speed Rail System \\
$\quad$ (Windsor to Quebec) \\
Lead Poisoning in Wildlife due to Lead-based \\
$\quad$ Hunting Projectiles \\
Problems with Locating Wind Energy Projects \\
Ontario Micro Feed-in-Tariff Program for Solar \\
$\quad$ Energy \\
Oilsands - Water Use and Pollution \\
Oilsands - Greenhouse Gas Emissions \\
Limits to Growth \\
Scenarios in IPCC 2007 Report \\
Smart Growth of Cities \\
Present and Future Mix of Electricity Sources in \\
Ontario \\
Is there a Clean Way to Burn Coal? \\
Indoor Air Quality Regulations \\
Bottled water - good or bad? \\
The Jevons Paradox \\
Kalamazoo oil spill (July 26, 2010) \\
USEPA Spill Plan regulation (SPCC 2010) \\
Nuclear Fusion \\
Environmental Effects of Manufacturing and \\
Disposing of Silicon Solar Cells \\
A topic of your choice if approved by the instructor \\
\hline
\end{tabular}

Table 2. Group Project Topics

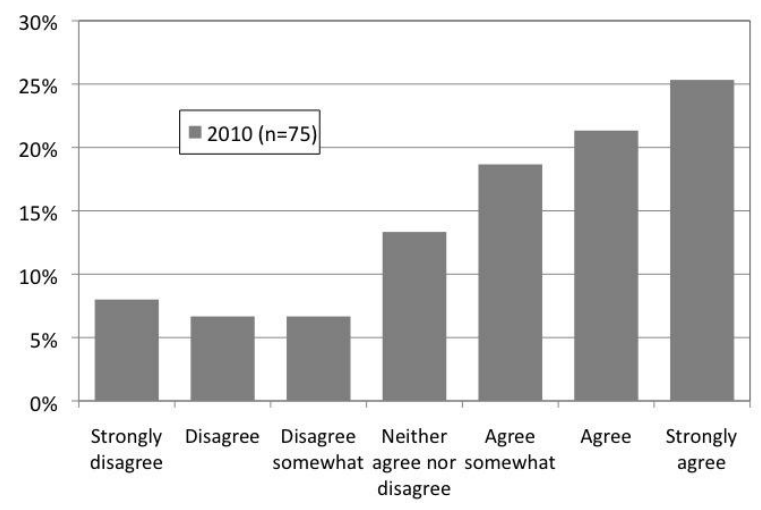

Figure 4. Student Responses to the Statement, "The group project was a worthwhile undertaking."

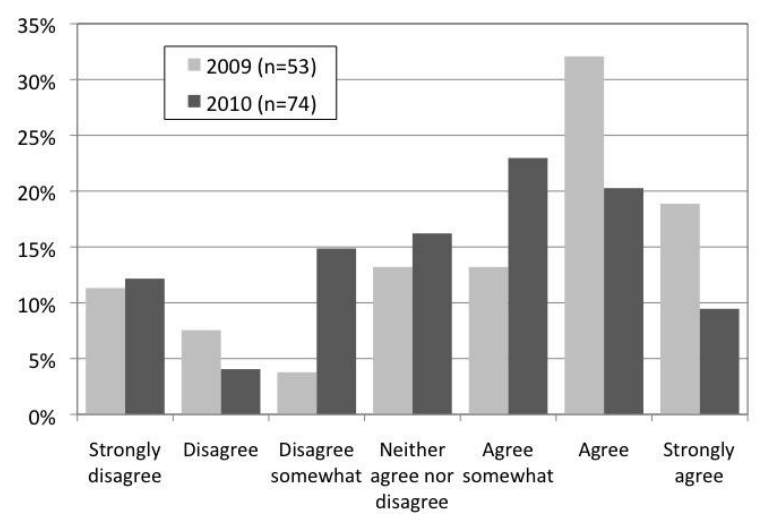

Figure 5. Student Responses to the Statement, "Reading the textbook helped me understand the material in the course."

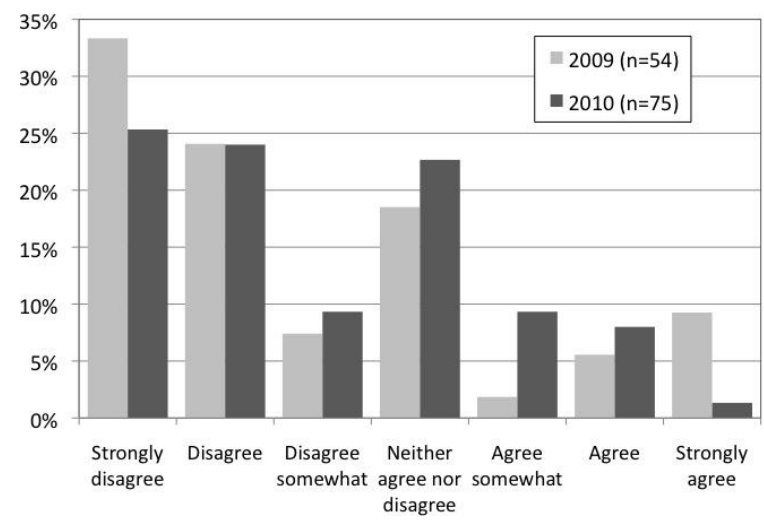

Figure 6. Student responses to the Statement, "The course was weighted too heavily towards qualitative concepts and there was not enough quantitative material (numbers).

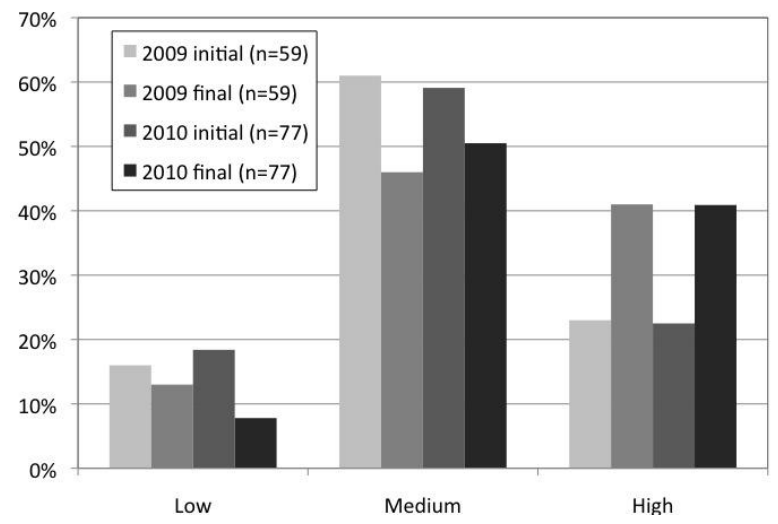

Figure 7. Student Responses to the Statements, "Your level of enthusiasm for taking this course at the time of initial registration (initial)", and "Your level of enthusiasm for taking the course at the conclusion of the course (final)." 
said "yes" in 2009 and 2010 respectively. The overall scores for the course, as separate from the instructor, were 5.5 out of 7 in 2009 and 5.8 in 2010, which is considered good, taking into account the size of the classes.

\section{Future Work}

85-250 will continue to be offered in the foreseeable future. Changes in the Engineers Canada exam syllabi will directly affect the course content. Overall however, students appreciate the delivery and evaluation methods in the course.

\section{References}

[1] Engineers Canada. (2010) Description of Exam Route [Online]. Available:

http://www.engineerscanada.ca/e/files/description_exa m_route_2010.pdf

[2] Engineers Canada. (1998) Complementary Studies Syllabus [Online]. Available:

http://www.engineerscanada.ca/e/files/syllabus_3.pdf

[3] Engineers Canada. (1998) Civil Engineering

Syllabus [Online]. Available:

http://www.engineerscanada.ca/e/files/syllabus_4_5.p df

[4] Canadian Engineering Accreditation Board. (2010) 2010 Accreditation Criteria and Procedures [Online]. Available:

http://www.engineerscanada.ca/e/files/Accreditation_ Criteria_Procedures_2010.pdf
[5] J.R. Mihelcic and J.B. Zimmerman, Environmental Engineering: Fundamentals, Sustainability, Design. Hoboken, NJ: John Wiley \& Sons, 2010.

[6] D.B. Botkin, E.A. Keller and I.W. Heathcote, Environmental Science: Earth as a Living Planet (Canadian Edition). Hoboken, NJ: John Wiley \& Sons, 2006.

[7] P.H. Raven, L.R. Berg and D.M. Hassenzahl, Environment (7th Edition). Hoboken, NJ: John Wiley \& Sons, 2008.

[8] Engineers Without Border/Ingenieurs Sans Frontieres. (retrieved May 2, 2011) Presenting Water for the World [Online]. Available: http://www.ewb.ca/en/whatwedo/canada/projects/hso/t eachers/w4w/index.html

[9] Epstein Educational Enterprises. (retrieved May 2, 2011) What is the IF-AT? [Online]. Available: http://www.epsteineducation.com/home/about/default. aspx

[10] D. DiBattista, "The Immediate Feedback Assessment Technique: A learner-centered multiplechoice response form," Canadian Journal of Higher Education, vol. 35, pp. 111-131.

[11] M. Martyn, "Clickers in the Classroom: An Active Learning Approach," EDUCAUSE Quarterly, vol. 30, no. 2. 